\title{
Design Compatibility of Classroom Furniture in Urban and Rural Preschools
}

\author{
Shivarti, ${ }^{1}$ U.V. Kiran ${ }^{2}$ \\ ${ }^{1,2}$ Department of Human Development \& Family Studies, School for Home Sciences, Babasaheb Bhimrao \\ Ambedkar University, Lucknow-226025.
}

\begin{abstract}
Classroom furniture design can affect educational activities because it is an important component in any classroom which helps in providing a comfortable and functional classroom environment for the children. Improper furniture design can result in defective posture which could affect children's academic performance. Hence it is essential to facilitate school furniture in accordance to the requirement of school children. To focus on the issue of furniture design the present study is conducted with an objective to identify the mismatch between the individual body dimensions of children and existing furniture in preschools. To carry out the objective, urban and rural preschools were selected randomly from the selected urban and rural areas of Lucknow district of Uttar Pradesh, India. The evaluation of the study was made by using the self made questionnaire standardized along with anthropometric checklist. The results of the study revealed mismatch between existing furniture (seat height, seat depth, and desk height) with children's body dimensions which may result in various health problems in later life.
\end{abstract}

Keywords: 'Classroom furniture', 'Design compatibility', 'Urban and rural preschools'

\section{Introduction}

Furniture is one of the important physical facilities provided in classrooms where the children spend most of their time working with different learning activities [1] like reading, writing, drawing and other related activities in the classroom, they sit continuously for long hours. Hence it is necessary that schools should be provided furniture that is fit to the requirement of school children. The use of poorly designed furniture that fails to accommodate the anthropometric characteristics of its user have a negative influence on human health. A surprising number of school children are reported to have regular back pain, neck pain and headache by using ill designed furniture that result in bad postural habits, while good posture habits reduces organ crowding, strain on soft bone and muscle. Most of the researches have revealed that in most of the schools, the furniture is designed by manufacturer without considering the anthropometric dimensions of the users of different age groups. As an outcome, benches and desks become unsuitable, uncomfortable, inconvenient, affecting classroom learning activities of school children while attending their classes [2]. Thus anthropometric measurements are an important factor that should be taken in to account the design of classroom furniture. Specific measurements, such as elbow rest height, popliteal height, buttock popliteal length, hip breadth are necessary in order to determine school furniture dimensions that facilitate correct sitting posture. Correct designed furniture that promotes proper posture is more important to children than adults because it is the biological stage of life where sitting habits are formed. Bad sitting habits that are acquired in childhood are very difficult to change in later life [3].

Classroom activities are strongly influenced by areas where schools are located and the facilities that are provided to the children in their schools. Recent studies have presented a conflicting picture of rural verses urban preschool qualities. A prominent study concludes that students in rural preschools in comparison to urban preschools perform less because of affected learning environment and classroom facilities. In rural preschools it is often seen that the same size of furniture are used in several classes either in pre-classes or in secondary. Urban preschools allocate various types of furniture for different classes. The reason is that such type of furniture is less costly to manufacture and easier to purchase at the lower price. The urban and rural preschools vary in terms of their facilities, type of education and furniture too because majority of urban preschools use good furniture, matched with the anthropometric dimensions of the students, reduces organ crowding and strain on soft bones and muscles. It can be seen that if the seat surface is too high the underside of the thighs becomes compressed causing discomfort and restriction in blood circulation. When the seat surface is too deep, the front edge of the seat will press into the area just behind the knee cutting off circulation; the person in the seat will slide forward but will lose proper backrest and support for the lower thighs.

Thus, good type of furniture, facilitate perfect match with the individual body dimensions would help to reduce, eventually eliminate stress during learning period in preschoolers because incorrect sitting posture pose extreme physiological strain on muscles. Hence the present study is taken up to identify the mismatch between the individual body dimensions of children and the existing furniture in preschools. 


\section{Research Methods}

\subsection{Sample Selection}

Lucknow District of Uttar Pradesh, India was selected purposively to conduct the present study. Multistage random sampling technique was used to select the sample for the present study. The list of zones and wards were obtained from the Lucknow Municipal Corporation (Census, 2001). Out of the existing six zones, two zones were selected randomly by using random sampling technique. From each zone, two wards were selected randomly after obtaining a list of them. From the selected areas, the lists of schools were obtained and from the existing no of schools, ten preschools each from urban and rural areas were selected randomly by using random sampling technique. From each preschool, the students studying in nursery, in the age group of below 6 years were identified and 20 respondents inclusive of 10 boys and 10 girls were selected randomly using random sampling technique. The sample size for the present study was computed using the given formula- $\boldsymbol{n}=\frac{z^{2} \mathbf{p q}}{\mathbf{E}^{2}}$. The total sample size is fixed as 400 .

\subsection{Data Collection}

Data sheet was prepared to acquire the anthropometric dimensions of sample and the measurement of existing furniture in both urban and rural preschools.

\subsection{Anthropometric Measurements}

To identify the mismatch between individual body dimensions and existing furniture the anthropometric dimensions were measured as given in table- 1 with the use of measuring tape in inches. All the anthropometric measurements were taken with the subject in a relaxed and erect posture. The subjects were wearing light clothes and were bare footed during measurement.

Table -1 Definition of Measured Anthropometric Dimensions to Identify the Mismatch

\begin{tabular}{|c|l|l|}
\hline $\begin{array}{c}\text { S. } \\
\text { No. }\end{array}$ & $\begin{array}{l}\text { Dimensions in Sitting } \\
\text { Posture }\end{array}$ & \multicolumn{1}{c|}{ Definition } \\
\hline 1 & Elbow rest height & $\begin{array}{l}\text { Height from the top of the sitting surface to the bottom of the tip of } \\
\text { the elbow. } \\
\text { Popliteal angle point at the underside to the thigh immediately behind } \\
\text { the knee, where the tendon of biceps and femor muscle insert. }\end{array}$ \\
\hline 2 & Popliteal height & $\begin{array}{l}\text { Horizontal distance from the rear most surface of the buttock to the } \\
\text { back of the lower leg. }\end{array}$ \\
\hline 3 & $\begin{array}{l}\text { Buttock popliteal } \\
\text { length }\end{array}$ & Maximum horizontal distance across the hips. \\
\hline 4 & Hip breadth & \multicolumn{2}{|c|}{} \\
\hline
\end{tabular}

\subsection{Dimensions of Existing Furniture}

The dimensions of classroom furniture, in randomly selected preschools were also measured as given in table 2 with the use of measuring tape in inches. The following variables represent relevant dimensions of classroom furniture (chairs, desks):-

Table 2- Classroom Furniture Measurements

\begin{tabular}{|c|l|l|}
\hline S. No. & Dimensions & \multicolumn{1}{c|}{ Definitions } \\
\hline 1 & Chair height & Vertical distance from the floor to the topmost part of the chair. \\
\hline 2 & Chair depth & $\begin{array}{l}\text { Horizontal distance of the sitting surface from the back of the seat to the front } \\
\text { of the seat. }\end{array}$ \\
\hline 3 & Chair breadth & $\begin{array}{l}\text { Horizontal distance from left hand side of the seat and the right hand side or } \\
\text { vice versa. }\end{array}$ \\
\hline 4 & Desk height & $\begin{array}{l}\text { Vertical distance from the floor to the top of the front edge of the desks. } \\
\text { Horizontal distance from the front of the desk to the back at the top of the } \\
\text { front edge of the shelf under the writing surface. }\end{array}$ \\
\hline 6 & Desk depth & $\begin{array}{l}\text { Horizontal distance from left hand side of the seat and the right hand side or } \\
\text { vice versa. }\end{array}$ \\
\hline
\end{tabular}

\subsection{Data Analysis}

The anthropometric data was statistically analyzed in averages, Standard Deviation and t- test statistic using SPSS. The mismatch between anthropometric dimensions of children and existing furniture was analyzed based on the equations which were given by various researchers to define mismatch, as listed below-

- Seat height mismatch- when the seat height was either $>95 \%$ or $<88 \%$ of the popliteal height [4], [5].

- Seat depth mismatch-when the seat depth was either $>95 \%$ or $<80 \%$ of the popliteal height [4], [5]. 
- Seat breadth mismatch- should be at least $10 \%$ to accommodate hip breadth and at most $30 \%$ larger than hip breadth [6]

- Desk height mismatch- when the desk height was at 95\% of sitting elbow height (Evans et al. 1988). Marmora's calculated that the desk should be $3-5 \mathrm{~cm}$ height than the elbow [6].

\section{Research Findings And Discussion}

\subsection{Anthropometric Dimensions-}

Anthropometric dimensions are the measurements of human body dimensions which present the physical characteristics of an individual. In the present study, to identify the mismatch between individual body dimensions and existing furniture in preschools, anthropometric measurements were taken from rural and urban preschool children. Data of each anthropometric parameter is presented by calculating Arithmetic mean, Standard Deviation (SD) in Table-1 and the significance of the differences across gender (boys and girls) and area (rural and urban) was determined by using t-test.

Table -1 Anthropometric dimensions of preschool children (in inches)

\begin{tabular}{|c|c|c|c|c|c|}
\hline \multirow{2}{*}{$\begin{array}{l}\text { Dimensions } \\
\text { In sitting posture }\end{array}$} & \multirow{2}{*}{$\begin{array}{l}\text { Urban/ } \\
\text { Rural } \\
\text { preschool }\end{array}$} & Boys & \multirow[t]{2}{*}{ t value } & Girls & \multirow{2}{*}{$\begin{array}{l}\mathrm{t} \\
\text { value }\end{array}$} \\
\hline & & Mean \pm SD & & Mean \pm SD & \\
\hline Sitting elbow height & $\begin{array}{l}\mathrm{U} \\
\mathrm{R}\end{array}$ & $\begin{array}{lll}5.64 & \pm & 0.90 \\
6.64 & \pm & 0.63\end{array}$ & $4.14 * *$ & $\begin{array}{lll}5.64 & \pm & 0.81 \\
6.32 & \pm & 0.62\end{array}$ & $3.31 * *$ \\
\hline Popliteal height & $\begin{array}{l}\mathrm{U} \\
\mathrm{R}\end{array}$ & $\begin{array}{lll}5.04 & \pm & 0.61 \\
5.56 & \pm & 0.91\end{array}$ & $2.14^{*}$ & $\begin{array}{lll}5.48 & \pm & 0.71 \\
5.44 & \pm & 0.65\end{array}$ & 0.20 \\
\hline $\begin{array}{l}\text { Buttock popliteal } \\
\text { length }\end{array}$ & $\begin{array}{l}\mathrm{U} \\
\mathrm{R}\end{array}$ & $\begin{array}{l}17.84 \pm 1.28 \\
18.28 \pm 1.69\end{array}$ & 1.04 & $\begin{array}{lll}17.56 & \pm & 0.86 \\
17.8 & \pm & 0.91\end{array}$ & 0.95 \\
\hline Hip breadth & $\begin{array}{l}\mathrm{U} \\
\mathrm{R}\end{array}$ & $\begin{array}{l}22.56 \pm 1.73 \\
23.28 \pm 2.22\end{array}$ & 1.25 & $\begin{array}{l}21.88 \pm 1.92 \\
22.24 \pm 2.36\end{array}$ & 1.05 \\
\hline
\end{tabular}

The measurements of boys and girls were found to be almost same with significant differences in rural and urban preschools. The data (table 1) presented, compared the anthropometric dimensions of rural and urban preschool boys and girls. The dimensions of rural preschoolers were more when compared to the urban preschoolers among both boys and girls. Highly significant differences were found with regard to the dimensions of sitting elbow height when urban preschool boys $(\mu=5.64)$ were compared with rural preschool boys $(\mu=6.64)$ and urban preschool girls $(\mu=5.64)$ with rural preschool girls (6.32). Significant differences were found in popliteal height of urban preschool boys $(\mu=5.04)$ and rural preschool boys $(\mu=5.48)$ which is considered non significant between rural preschool boys $(\mu=5.56)$ and rural preschool girls $(\mu=5.44)$. Non significant differences were found in both buttock popliteal length and hip breadth of preschoolers in urban and rural preschool boys and girls.

\subsection{Furniture Profile-}

The dimensions of furniture in urban and rural preschools were measured to find out the mismatch of the classroom furniture with children's body dimensions. The mean, standard deviation and $t$ value of the same are presented in the Table 2 . The proposed dimensions of the classroom furniture were calculated and presented in Table 3 to evaluate the mismatch between children's body dimensions and furniture design.

Table -2 Mean and SD values of Existing furniture in urban and rural preschools.

\begin{tabular}{|l|c|c|c|c|c|}
\hline \multirow{2}{*}{$\begin{array}{l}\text { Furniture } \\
\text { measurement }\end{array}$} & \multicolumn{2}{|c|}{ Urban preschool } & \multicolumn{2}{c|}{ Rural preschool } & t value \\
\cline { 2 - 5 } & Mean & SD & Mean & SD & \\
\hline Table depth & 11.8 & 0.44 & 11.2 & 0.83 & 0.5 \\
\hline Table breadth & 15.4 & 1.34 & 14.6 & 2.60 & $2^{*}$ \\
\hline Table height & 20.8 & 3.27 & 19 & 2.82 & $3^{*}$ \\
\hline Chair depth & 10.6 & 0.89 & 9.4 & 1.34 & $5.28^{* *}$ \\
\hline Chair breadth & 14 & 2.54 & 13.8 & 2.48 & 0.39 \\
\hline Chair height & 14.4 & 6.06 & 12 & 1.73 & $2.64^{*}$ \\
\hline
\end{tabular}

Significant differences were observed in the dimensions of student's furniture in pre- schools. The students seating furniture inclusive of table and chair were studied in case of chair and table the height, the depth and the breadth were studied which are the key factors in providing comfort for the child, avoiding 
Design Compatibility Of Classroom Furniture In Urban And Rural Preschools

postural comfort for the child, avoiding postural problems and accidents. Significant differences were found in the furniture existing in urban and rural preschools.

Table -3 Mismatch of existing furniture with children body dimensions (in inches).

\begin{tabular}{|l|l|c|l|c|l|}
\hline Dimensio & \multicolumn{1}{|c|}{ Range } & \multicolumn{2}{|c|}{ Urban preschool } & \multicolumn{2}{c|}{ Rural preschool } \\
\cline { 3 - 6 } & Existing & $\begin{array}{l}\text { Calculated/ } \\
\text { Proposed }\end{array}$ & Existing & $\begin{array}{l}\text { Calculated/ } \\
\text { Proposed }\end{array}$ \\
\hline Seat height & $\begin{array}{l}\text { Popliteal height }>95 \% \text { or } \\
<80 \%\end{array}$ & 15.8 & $4.78-4.43$ & 12 & $5.28-4.89$ \\
\hline Seat depth & $\begin{array}{l}\text { Popliteal to Buttock Length } \\
>95 \% \text { or }<80 \%\end{array}$ & 10.6 & $14.27-16.95$ & 9.6 & $14.62-17.36$ \\
\hline $\begin{array}{l}\text { Seat } \\
\text { breadth }\end{array}$ & $\begin{array}{l}\text { Hip breadth + 10\% or } \\
<30 \%\end{array}$ & 14 & $24.81-7.44$ & 13.8 & $25.60-7.68$ \\
\hline $\begin{array}{l}\text { Desk } \\
\text { height }\end{array}$ & Sitting elbow height 95\% & 14.4 & 5.35 & 12 & 6.30 \\
\hline
\end{tabular}

Considering the anthropometric measurements among urban and rural preschools, the mismatch of existing furniture was calculated and the comfortable dimensions of furniture is proposed for both urban and rural preschools as there were significant differences in the anthropometric dimensions of the preschoolers. The proposed furniture dimensions were calculated using the ranges as given by Parcells et al (1999).

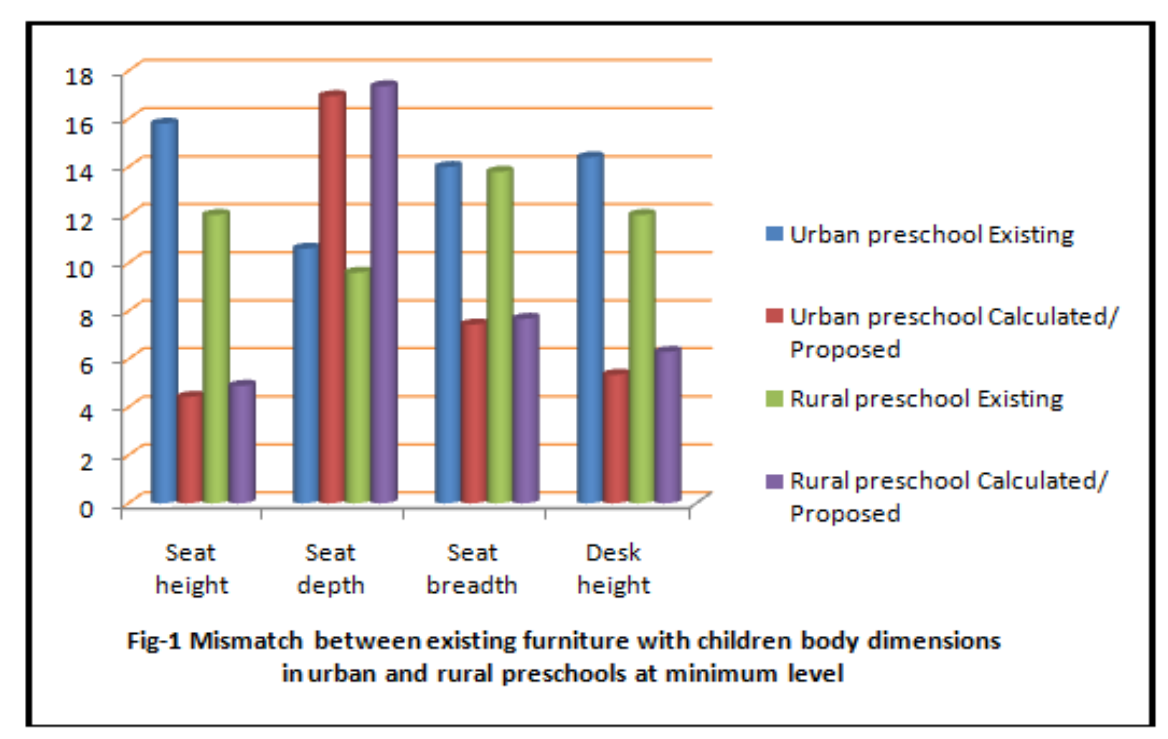

It is observed that the existing seat height of both urban and rural preschools is higher than proposed dimensions (Table 3 and Fig 1) this forces the child to keep their feet hanging in the air which induces discomfort and pain in the legs and back.

Mismatches were found between seat height, seat depth and desk height of existing furniture in urban and rural preschools when calculated with the anthropometric dimensions of preschoolers such as popliteal height, popliteal to buttock length and seating elbow height of the preschoolers. Popliteal height is considered to understand the impact of chair height. If the seating surface is too high, the undersides of the thigh become compressed causing discomfort and restriction in blood circulation and feet do not have proper contact with the floor or footrest which weakens the body stability. The seat depth of urban and rural preschools was found to be low in the existing furniture than the proposed dimensions. Seat depth is useful to facilitate the suggested $80 \%$ flexion of the knee for rising out of the chair and for leg movement. Low seat depth may cause the children to have the sensation of falling off the front of the chair and result in lack of support of the lower thighs. Elbow rest height is important in studying posture. If the elbow rest height is lower than the desk surface, the arm and shoulder must be raised during writing, resulting stress on the neck and to provide stabilization of the head posture. If the elbow rest height exceeds than the desk height will result in the children forward by spinal flexion, with body weight being supported by the arms $[6,7,8]$.

The seat breadth of the existing furniture was found to be higher than the proposed dimensions. This may not create any discomfort to the child and moreover the child with larger dimensions of buttock and thigh can also be easily accommodated. 

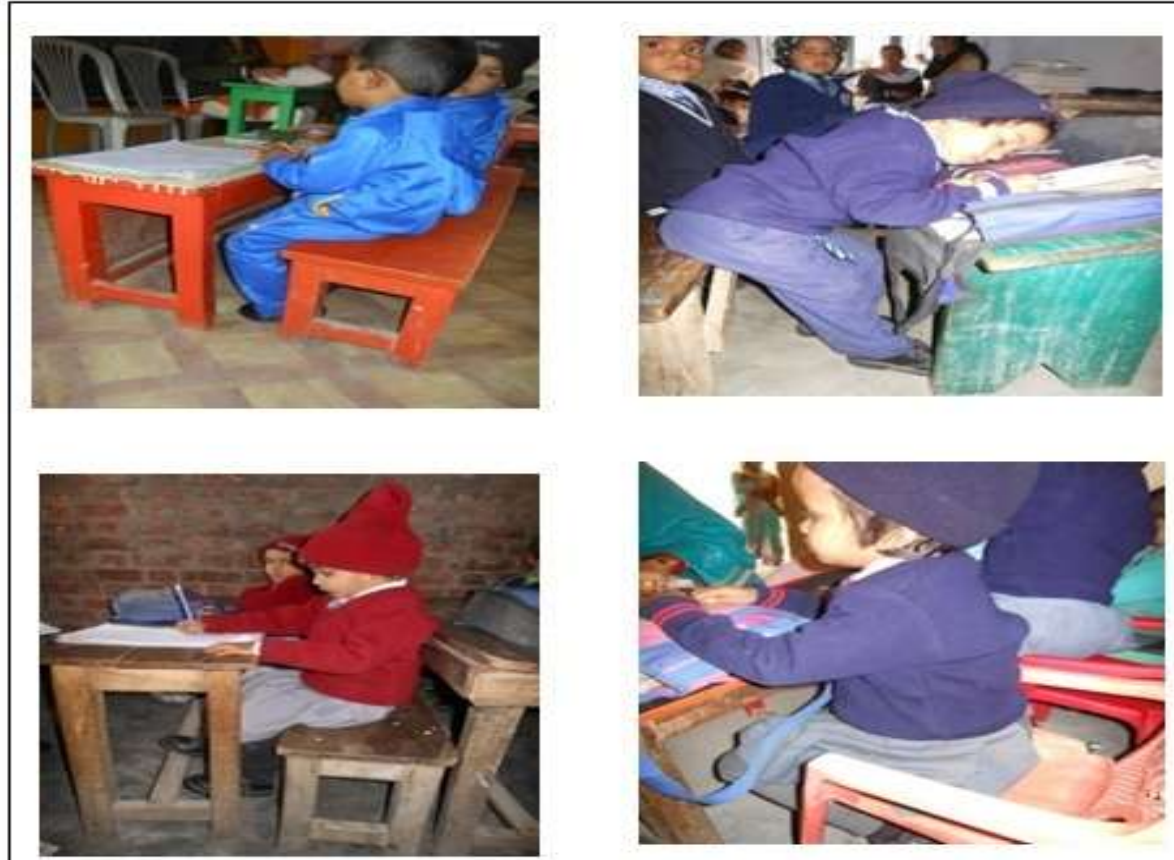

Fig-2 Children sitting in uncomfortable posture due to the mismatch of furniture design.

\section{Conclusion}

The present study was able to establish a picture of mismatch between body dimensions of children and existing furniture in rural v/s urban preschools. The study reveals that the mismatch of existing furniture among both the preschools is due to ignorance of anthropometric measurements of children during manufacturing of the furniture. The information emerged out of the study revealed that the furniture provided in preschools do not match with body dimensions of furniture. The seat height, seat depth, and desk height do not match with the children's body dimensions in both urban and rural preschools. Due to mismatch of furniture design with body dimensions children faced posture related problems during work in their classrooms. Thus it is essential to make classroom furniture user friendly, designing each component of furniture by considering the body dimensions of user carefully. Government has to interfere and make strict policies regarding the type of furniture to be used in preschool. The differences in urban and rural preschools also have to be minimized "as a child, anywhere is a child- "a tender bundle of softness in need of protection".

\section{References}

[1] Khanam C.N; Reddy M.V; and MrunaliniA. (2006). Designing Student's Seating Furniture for Classroom Environment. J. Hum. Ecol., 20(4): 241-248.

[2] Dhara P.C; Khaspuri G; Sau S.K. (2009). Complaints arising from a mismatch between school furniture and anthropometric measurements of rural secondary school children during class work. Environ Health Prev. Med, 14:36-45.

[3] Daneshmandi H;Isanezhad A;Hematinezhad M. (2008). The effect of classroom furniture on back, neck, lumbar and leg fatigue in student. Journal of Movement Science and Sports, 1:37-44.

[4] Hafezi R; Mirmohammadi S.J; Mehrparvar A.H; Akbari, H. (2010). An analysis of anthropometric data on Iranian primary school children. Iranian Journal of Public. Health, 39(4):78-86.

[5] Ismaila S.O; Akanbi O.G; Oderinu S.O. (2010). Anthropometric survey and appraisal of furniture for Nigerian primary school pupils. Journal Science and Tech (4) 29-36.

[6] Parcells C, Manfred S, Hubbard R. (1999). Mismatch of classroom furniture and body dimensions. Empirical findings and health implications. Journal of Adolescent Health, 24(4):265-73

[7] Ghazilla R.A.R; Taha Z; Kamaruddin, S; Hasanuddin I. (2010). Pilot investigation on the mismatches of classroom furniture and student body dimensions in Malaysian Secondary Schools. Journal of Social Sciences, 6(2):287-292.

[8] Gouvali M.K; Boundolos K. (2006). Match between school furniture dimensions and children's anthropometry. Applied Ergonomics, 37:765-773. 